\title{
Protease-Resistant Human Prion Protein and Ferritin Are Cotransported across Caco-2 Epithelial Cells: Implications for Species Barrier in Prion Uptake from the Intestine
}

\author{
Ravi Shankar Mishra, ${ }^{\star}$ Subhabrata Basu, ${ }^{\star}$ Yaping Gu, Xiu Luo, Wen-Quan Zou, Richa Mishra, Ruliang Li, Shu G. Chen, \\ Pierluigi Gambetti, Hisashi Fujioka, and Neena Singh \\ Institute of Pathology, Case Western Reserve University, Cleveland, Ohio 44106
}

\begin{abstract}
Foodborne transmission of bovine spongiform encephalopathy (BSE) to humans as variant Creutzfeldt-Jakob disease (CJD) has affected over 100 individuals, and probably millions of others have been exposed to BSE-contaminated food substances. Despite these obvious public health concerns, surprisingly little is known about the mechanism by which $\operatorname{PrP}-$ scrapie $\left(\mathrm{PrP}^{\mathrm{Sc}}\right)$, the most reliable surrogate marker of infection in BSE-contaminated food, crosses the human intestinal epithelial cell barrier. Here we show that digestive enzyme (DE) treatment of sporadic CJD brain homogenate generates a C-terminal fragment similar to the proteinase K-resistant $\operatorname{PrP}^{\mathrm{Sc}}$ core of $27-30 \mathrm{kDa}$ implicated in prion disease transmission and pathogenesis. Notably, DE treatment results in a $\operatorname{PrP}^{\mathrm{Sc}}$-protein complex that is avidly transcytosed in vesicular structures across an in vitro model of the human intestinal epithelial cell barrier, regardless of the amount of endogenous $\operatorname{PrP}^{\mathrm{C}}$ expression. Unexpectedly, $\mathrm{PrP}^{\mathrm{Sc}}$ is cotransported with ferritin, a prominent component of the DE-treated $\mathrm{PrP}^{\mathrm{Sc}}$ protein complex. The transport of $\operatorname{PrP}^{\mathrm{Sc}}$-ferritin is sensitive to low temperature, brefeldin-A, and nocodazole treatment and is inhibited by excess free ferritin, implicating a receptor- or transporter-mediated pathway. Because ferritin shares considerable homology across species, these data suggest that $\mathrm{PrP}^{\mathrm{Sc}}$-associated proteins, in particular ferritin, may facilitate $\operatorname{PrP}^{\mathrm{Sc}}$ uptake in the intestine from distant species, leading to a carrier state in humans.
\end{abstract}

Key words: prion infection; subclinical infection; PrP transport; new variant CJD; ferritin; epithelial cell barrier; Caco-2

\section{Introduction}

The transmission of sheep scrapie to cattle as bovine spongiform encephalopathy (BSE) and its onward transmission to humans as variant Creutzfeldt-Jakob disease (vCJD) attests to the remarkably persistent and permeable nature of prions or PrP-scrapie $\left(\mathrm{PrP}^{\mathrm{Sc}}\right)$ across species barriers (Hill et al., 1998; Collinge, 1999; Taylor, 2002). The BSE epidemic is far from over despite the concerted efforts of national, industrial, and regulatory agencies across the world. An emerging threat is the continual spread of chronic wasting disease in the deer and elk population in the United States and the uncertainties regarding its transmission to livestock and humans (Miller and Williams, 2003). As the sources of $\mathrm{PrP}^{\mathrm{Sc}}$-contaminated food products continue to increase, it has become increasingly critical to understand the mechanism by which $\mathrm{PrP}^{\mathrm{Sc}}$, a protein with a protease-resistant core of $27-30$ $\mathrm{kDa}$ and a major, if not the only, component of prion infectivity

\section{Received July 15, 2004; revised 0ct. 27, 2004; accepted Nov. 2, 2004}

This work was supported by National Institutes of Health Grants NS39089 and NS44209 to N.S. Normal and sporadic Creutzfeldt-Jakob disease human brain tissue was obtained from the National Prion Disease Surveillance Center and processed in the biosafety level 3 facility (supported by grants from the Centers for Disease Control and Prevention to P.G.). Technical assistance for the processing of electron microscopic sections was provided by KietDan Luc.

* R.S.M. and S.B. contributed equally to this work.

Correspondence should be addressed to Dr. Neena Singh, Institute of Pathology, Case Western Reserve University, 2085 Adelbert Road, Cleveland, OH 44106. E-mail: neena.singh@case.edu.

DOI:10.1523/JNEUROSCI.2864-04.2004

Copyright $\odot 2004$ Society for Neuroscience 0270-6474/04/2411280-11\$15.00/0
(Prusiner, 1998), maneuvers its way across the impermeable and highly selective epithelial barrier of the human intestinal tract.

Retrospective examination of vCJD patients and animal models challenged orally with BSE-infected tissue show accumulation of $\mathrm{PrP}^{\mathrm{Sc}}$ in the Peyer's patches, lymphoid tissue lining the gastrointestinal (GI) tract, and peripheral and enteric nervous systems (Bons et al., 1999; Beekes and McBride, 2000; Foster et al., 2001; McBride et al., 2001; Nicotera, 2001; Haik et al., 2003; Aguzzi and Polymenidou, 2004). Uptake of $\operatorname{PrP}^{\mathrm{Sc}}$ from the lumen of the intestine is thought to be mediated by intestinal dendritic cells and M-cells lining the mucosa, after which it undergoes replication in the gut-associated lymphoid tissue. Subsequent transport to the CNS probably occurs along peripheral nerves (Heppner et al., 2001; Huang et al., 2002; Aguzzi and Polymenidou, 2004). However, a recent report demonstrating the absence of prion infectivity in $\mu \mathrm{MT}$ and RAG1 ${ }^{-/-}$mice orally challenged with prions despite the presence of $\mathrm{M}$-cells suggests that $\operatorname{PrP}^{\mathrm{Sc}}$ transport across the intestinal epithelial barrier is not limited to M-cells and that additional pathways must exist (Prinz et al., 2003).

Thus, to fully understand the mechanism of $\operatorname{PrP}^{\mathrm{Sc}}$ uptake from contaminated food by the intestinal epithelial cells, we investigated the transport of human $\mathrm{PrP}^{\mathrm{Sc}}$ from sporadic CJD brain tissue ( $\mathrm{sCJD}-\mathrm{PrP}^{\mathrm{Sc}}$ ) across a monolayer of Caco-2 cells with tight junctions, representing an in vitro model of the human intestinal epithelial cell barrier (Pinto et al., 1983). Here we show that pre- 
treatment of sCJD brain homogenate with digestive enzymes (DEs), in particular stomach pepsin, generates a proteaseresistant C-terminal fragment similar to the proteinase $\mathrm{K}(\mathrm{PK})$ resistant core of $\mathrm{PrP}^{\mathrm{Sc}}(\mathrm{PrP} 27-30)$ implicated in the transmission and pathogenesis of prion disorders (Prusiner, 1998). Unexpectedly, both $\mathrm{PK}$ and $\mathrm{DE}$ treatments generate a $\mathrm{PrP}^{\mathrm{Sc}}$-protein complex that includes ferritin as a major component, and the $\operatorname{PrP}^{\mathrm{Sc}}$ ferritin complex is cotransported across Caco-2 cells in vesicular structures. The transport of $\mathrm{PrP}^{\mathrm{Sc}}$-ferritin complex is inhibited by excess free ferritin, low temperature, and by treatment with brefeldin-A or nocodazole, implicating a receptor- or transportermediated transcytotic path across Caco- 2 cells. These data provide insight into the cellular mechanisms by which $\operatorname{PrP}^{\mathrm{Sc}}$ ingested with contaminated food crosses the intestinal epithelium and the possibility of devising practical methods for blocking its uptake.

\section{Materials and Methods}

Materials and chemicals. Normal human brain tissue was obtained from frozen samples from a 61-year-old female and diseased tissue from a 66-year-old male with a confirmed diagnosis of sCJD. Human colon carcinoma cell lines Caco-2 (C2BBe1) (Peterson et al., 1992) and HT-29 were obtained from American Type Culture Collection (Manassas, VA). The following anti-PrP antibodies were used in this study: 3F4 (residues 109 and 112; Signet Laboratories, Dedham, MA), 8H4 (residues 175-185; obtained from our facility), 8B4 (residues 37-44; obtained from our facility), and 6H4 (residues 144-152; Prionics). The antibody against the tight junction protein zonula occludens-1 (ZO-1) was purchased from Zymed (San Francisco, CA). Polyclonal anti-ferritin antibody was obtained from Sigma (St. Louis, MO). RITC- and FITC-labeled secondary antibodies were obtained from Southern Biotechnology (Birmingham, AL). Sulfo-NHS-biotin and streptavidin-Texas Red were obtained from Pierce (Rockford, IL). Cell culture supplies were obtained from Invitrogen (Carlsbad, CA). Pure human liver and spleen ferritin and all other chemicals were obtained from Sigma.

Cell culture and preparation of epithelial cell monolayers. Caco-2 cells were cultured in DMEM supplemented with $10 \%$ fetal bovine serum in a $10 \% \mathrm{CO}_{2}$ atmosphere and passaged weekly. For preparing monolayers, cells from a confluent flask were resuspended in DMEM at a concentration of $2 \times 10^{8}$ cells $/ \mathrm{ml}$ and added to the apical (AP) chamber of polycarbonate filters [Transwell; 12 or $24 \mathrm{~mm}$ diameter $\left(1\right.$ and $4.7 \mathrm{~cm}^{2}$, respectively); $3 \mu \mathrm{m}$ pore size; Costar, Cambridge, MA]. The filters were placed in a 12- or 6-well culture dish containing 0.6 or $1.2 \mathrm{ml}$ of DMEM, respectively. The medium was replaced every day until confluent monolayers with tight junctions developed (10-14 d). The integrity of tight junctions was monitored by measuring transepithelial electrical resistance (TEER) across the monolayer with a millicell-ERS instrument (Millipore, Bedford, MA) and by measuring the transfer of ${ }^{3} \mathrm{H}$-inulin from the AP to the basolateral (BL) chamber. Monolayers exhibiting a TEER of $>400 \Omega / \mathrm{cm}^{2}$ and a ${ }^{3} \mathrm{H}$-inulin transport of $<0.01 \% / \mathrm{cm}^{2} / \mathrm{min}$ after $1 \mathrm{hr}$ of incubation at $37^{\circ} \mathrm{C}$ were used for transport studies. For some studies, M17 cells cultured on polylysine-coated glass coverslips were placed in the BL chamber for the duration of the experiment.

Transfection of Caco-2 cells. The coding sequence of human PrP was subcloned into the eukaryotic expression vector cep $4 \beta$ using the Not $\mathrm{I}$ and BamHI restriction sites as described previously (Petersen et al., 1996) and transfected into Caco-2 cells with LipofectAMINE according to the manufacturer's (Invitrogen, Grand Island, NY) specifications. Transfected cells were selected and maintained in selective medium $(500 \mu \mathrm{g} / \mathrm{ml}$ hygromycin) at $37^{\circ} \mathrm{C}$ in a humidified atmosphere supplemented with $10 \% \mathrm{CO}_{2}$.

Preparation of DE- and PK-treated brain homogenates and immunoprecipitation. For sample preparation, $0.1 \mathrm{gm}$ of brain tissue from the frontal cortex was sonicated in $1 \mathrm{ml}$ of PBS to obtain a 10\% homogenate. Treatment with DEs was performed as described by Glahn et al. (1998). In short, $0.5 \mathrm{ml}$ of $10 \%$ normal homogenate $(\mathrm{NH})$ or sCJD homogenate $(\mathrm{CJDH})$ in $\mathrm{PBS}$ was treated with $200 \mathrm{U}$ of salivary amylase at $37^{\circ} \mathrm{C}$ for 15 $\mathrm{min}$. The $\mathrm{pH}$ of the solution was adjusted to 2.0 with $5.0 \mathrm{M} \mathrm{HCl}$, and 0.05 $\mathrm{ml}$ of pepsin $(4095 \mathrm{U})$ was added. After additional rocking at $37^{\circ} \mathrm{C}$ for 1 $\mathrm{hr}$, the $\mathrm{pH}$ was raised to 6.0 with $1 \mathrm{M}$ sodium bicarbonate, and $0.2 \mathrm{ml}$ of pancreatin-bile extract was added $(0.00185 \mathrm{gm}$ of pancreatin and 0.011 gm of bile extract $/ \mathrm{ml}$ of $0.1 \mathrm{M} \mathrm{NaHCO}_{3}$ ). The $\mathrm{pH}$ was raised to 7.4 with $6 \mathrm{~N}$ sodium hydroxide, and $0.0084 \mathrm{ml}$ each of $2 \mathrm{M} \mathrm{NaCl}$ and $\mathrm{KCl}$ solutions was added. The mixture was again rocked at $37^{\circ} \mathrm{C}$ for $2 \mathrm{hr}$. At the end of the digestion, the added enzymes were inactivated with 4 mм PMSF and a mixture of protease inhibitors containing $10 \mu \mathrm{g} / \mathrm{ml}$ each of leupeptin, antipain, and pepstatin, and the digest was stored at $-70^{\circ} \mathrm{C}$ for additional use. The same mixture of protease inhibitors was used throughout this study.

For PK treatment, the homogenate was supplemented with lysis buffer ( $1 \% \mathrm{NP}-40,0.5 \%$ sodium deoxycholate, $100 \mathrm{~mm} \mathrm{NaCl}$, and $10 \mathrm{~mm}$ EDTA in $20 \mathrm{~mm}$ Tris- $\mathrm{HCl}, \mathrm{pH} 7.4$ ) and treated with $50 \mu \mathrm{g} / \mathrm{ml} \mathrm{PK}$ at $37^{\circ} \mathrm{C}$ for 1 hr. The reaction was terminated with $4 \mathrm{~mm}$ PMSF and a mixture of protease inhibitors (described above), and the homogenate was frozen at $-70^{\circ} \mathrm{C}$ for additional use.

For immunoprecipitation, untreated or PK- or DE-treated NHs and sCJDHs were centrifuged at $3000 \times g$ for $15 \mathrm{~min}$ at $4^{\circ} \mathrm{C}$, and the supernatant was subjected to immunoprecipitation with either anti-ferritin or anti- $\mathrm{PrP}$ antibodies $6 \mathrm{H} 4$ or $8 \mathrm{H} 4$, as described previously (Mishra et al., 2002). The protein complexes were eluted from protein A beads with low $\mathrm{pH}$ glycine buffer, the $\mathrm{pH}$ was adjusted, and small aliquots of immunoprecipitated samples were frozen for additional use. Transport studies were performed in duplicate with each of these samples simultaneously to minimize experimental error.

Purification of $\operatorname{Pr} P^{S c}$ from $s C J D$ brain homogenate. For the isolation of purified $\mathrm{PrP}^{\mathrm{Sc}}, 0.3$ gm of sCJD brain sample was homogenized in PBS to yield a $10 \%$ homogenate and biotinylated with $1 \mathrm{mg} / \mathrm{ml}$ sulfo-NHSbiotin (Pierce) overnight at $4^{\circ} \mathrm{C}$. Excess biotin was quenched with $50 \mathrm{~mm}$ glycine and by washing three times with PBS in a centricon with a $3 \mathrm{kDa}$ cutoff. Biotinylated CJDH was supplemented with an equal volume of $2 \times$ lysis buffer and centrifuged at $890 \times g$ for 10 min to pellet large aggregates (P1). The recovered supernatant (S1) was ultracentrifuged at $100,000 \times g$ for $1 \mathrm{hr}$ at $4^{\circ} \mathrm{C}$ to obtain the pellet P2, which was resuspended again in lysis buffer and recentrifuged to obtain the pellet P3. At this stage, the pellet was redissolved in TNSS buffer ( $10 \mathrm{~mm}$ Tris, $1 \mathrm{~mm}$ EDTA, $1 \mathrm{~mm}$ DTT, $1 \%$ sarcosyl, and $135 \mathrm{~mm} \mathrm{NaCl}$ ) and treated with $50 \mu \mathrm{g} / \mathrm{ml} \mathrm{PK}$ at $37^{\circ} \mathrm{C}$ for $1 \mathrm{hr}$. The reaction was stopped with $4 \mathrm{~mm}$ PMSF and the mixture of protease inhibitors and subjected to an additional round of ultracentrifugation at $200,000 \times g$ for $2 \mathrm{hr}$ to obtain the $\mathrm{PrP}^{\mathrm{Sc}}$-rich pellet fraction P4. The pellet P4 was resuspended again in TNSS buffer and recentrifuged at the same speed to obtain sequentially pellet fractions $\mathrm{P} 5$ and P6. In parallel, normal brain tissue was subjected to a similar treatment and used as a control for transport and binding experiments. The pellet $\mathrm{P} 6$ obtained from both sCJD and normal brain tissue was resuspended in $100 \mu \mathrm{l}$ of PBS and sonicated with an equal volume of $20 \%$ purified human brain total lipid extract obtained from Avanti Polar Lipids (Alabaster, $\mathrm{AL}$ ) to yield a 10\% lipid-protein mixture. The resulting $\mathrm{NH}^{\text {Pellet }}$ - and $\mathrm{CJDH}^{\text {Pellet }}$-brain lipid suspensions were diluted in PBS containing $1 \% \mathrm{BSA}$ and used for binding and competition experiments.

Measurement of $P r P^{S c}$ transport. In a typical experiment, monolayers of Caco- 2 cells were washed with serum-free medium, and $20 \mu \mathrm{l}$ of sample dissolved in $1 \mathrm{ml}$ of serum-free medium was added to the AP chamber. The sample consisted of $\mathrm{NH}$ or $\mathrm{CJDH}$ that was untreated, $\mathrm{PK}$ or DE treated, or DE treated and mixed with $10 \mu \mathrm{M}$ PrP peptide 106-126. The inserts were placed in a 6-well dish containing $1.2 \mathrm{ml}$ of serum-free medium and incubated overnight at $37^{\circ} \mathrm{C}$. Subsequently, AP and BL media samples were collected and centrifuged to pellet cell debris, and proteins from the supernatant were isolated by cold methanol precipitation. For preparation of cell lysate, cells on monolayers were treated with lysis buffer, and proteins were precipitated as above. All samples were boiled in sample buffer, resolved by SDS-PAGE, electroblotted to a polyvinylidene difluoride (PVDF) membrane, and probed with specific antibodies.

Quantitative analysis was performed by measuring the total raw density of $\mathrm{PrP}^{\mathrm{Sc}}$ bands in the AP and BL medium from duplicate samples. Each experiment was repeated five to eight times, and the statistical significance was evaluated by Student's $t$ test. 
Silver staining of total proteins. After SDS-PAGE, proteins were stained with the silver staining kit according to the instructions provided by the manufacturer (Bio-Rad, Hercules, CA).

Competitive inhibition experiments. Caco-2 monolayers cultured on filter inserts were cut out with a sharp scalpel and inverted with the cell side down on $16 \mu \mathrm{l}$ of $\mathrm{NH}^{\text {Pellet }}$ or $\mathrm{CJDH}^{\text {Pellet }}$ suspension mixed in $84 \mu \mathrm{l}$ of PBS containing $1 \%$ BSA or $0,0.5,1.0$, and $1.5 \mu \mathrm{g} / \mathrm{ml}$ human spleen or liver ferritin dissolved in the same buffer. After a $30 \mathrm{~min}$ incubation on ice, filters were removed and washed gently in ice-cold PBS. Subsequent incubation with the specified sample was performed similarly. The cells were then fixed with $4 \%$ paraformaldehyde, immunostained as such on filters, and mounted with the cell side facing the coverslip for confocal microscopy.

Immunostaining and confocal microscopy. Cells were cultured on polyD-lysine-coated glass coverslips or on transparent Transwell filters. After a particular experimental treatment, cells were fixed and processed for staining or first permeabilized with Triton X-100 and reacted with one of the following primary antibodies: monoclonal anti-PrP $8 \mathrm{H} 4$ (1:20), polyclonal rabbit anti-ferritin (1:20), or polyclonal anti-ZO-1 (1:20), followed by RITC- or FITC-conjugated appropriate (mouse or rabbit) secondary antibodies as described previously ( $\mathrm{Gu}$ et al., 2003a,b). Streptavidin-Texas Red was used at a concentration of 1:40. Immunostained cells were mounted in gel mount and observed using a laserscanning confocal microscope (Bio-Rad MRC 600). Horizontal sections were imaged using a $60 \times$ objective, and a magnification of 1.0 or 2.5 at different depths beginning from the top of the cells until the filter pores were visible. Vertical images were captured similarly using one filter at a time (green or red). Selected samples were reexamined and imaged using the LSM 5105 confocal microscope (Zeiss, Oberkochen, Germany).

Electron microscopy (transmission electron microscopy). Caco- 2 cells on filter inserts were exposed to $8 \mathrm{H} 4$-immunoprecipitated CJDH-PrP ${ }^{\mathrm{Sc}}$ for $2 \mathrm{hr}$ and fixed in a buffer containing glutaraldehyde (2.5\%), paraformaldehyde $(2 \%)$, and sucrose $(4 \%)$ in phosphate buffer $(0.05 \mathrm{M}$, pH 7.4) for $2 \mathrm{hr}$. Cell monolayer on the filter was cut out of the inserts and postfixed with $1 \%$ osmium tetroxide for $1 \mathrm{hr}$, followed by $30 \mathrm{~min}$ of en bloc staining with $1 \%$ aqueous uranyl acetate. Cells were then dehydrated in ascending concentrations of ethanol and embedded in Epon 812. Ultrathin sections were treated with $1 \%$ periodic acid for $4 \mathrm{~min}$ and stained with $2 \%$ uranyl acetate and lead citrate in $50 \%$ methanol. Processing of the $8 \mathrm{H} 4-$ immunoprecipitated material was similar, with the modification that the sample was fixed, osmicated and treated with uranyl acetate in solution, and embedded in agar by centrifugation on a $1.5 \%$ agar block in an Eppendorf tube. The Eppendorf tube was then cut open with a blade, and the pellet embedded in agar was dehydrated and processed as above. All samples were examined using a CEM902 electron microscope (Zeiss).

\section{Results}

\section{Human $\mathrm{SCJD}-\mathrm{PrP}^{\mathrm{Sc}}$ is partially proteolyzed by DEs}

$\mathrm{PrP}^{\mathrm{Sc}}$ ingested with contaminated meat is exposed to the harsh environment within the GI tract before uptake by the lining epithelium. During this process, the effect of DE and variable $\mathrm{pH}$ on the structure and stability of $\operatorname{PrP}^{\mathrm{C}}$ and $\mathrm{PrP}^{\mathrm{Sc}}$ are not known. To address this question, samples of $\mathrm{NH}$ and $\mathrm{CJDH}$ were subjected to sequential treatment with DE to simulate the in vivo conditions. Beginning with amylase at $\mathrm{pH} 7.4$, the homogenates were sequentially treated with pepsin at $\mathrm{pH} 2.0$, followed by pancreatin and bile extract at $\mathrm{pH}$ 6.0.

The effect of DE on $\mathrm{PrP}^{\mathrm{Sc}}$ was compared with conventional PK treatment by subjecting mock-treated, PK-treated, and DEtreated samples to Western blot analysis with anti-PrP antibody 3F4. Mock-treated NH reveals the diglycosylated, monoglycosylated, and unglycosylated forms of $\mathrm{PrP}^{\mathrm{C}}$ migrating at 35-37, $28-$ 30 , and $27 \mathrm{kDa}$ respectively (Fig. $1 A$, lane 1 ). Similar glycoforms are detected in mock-treated $\mathrm{CJDH}$, although the ratio of the three glycoforms is altered (Fig. 1A, lane 4). Treatment with PK or DE results in complete proteolysis of $\mathrm{PrP}^{\mathrm{C}}$ in $\mathrm{NH}$ (Fig. $1 A$, lanes 2,3), whereas CJDH samples show faster migrating forms of 27-30 and $19 \mathrm{kDa}$, consistent with the migration of infectious

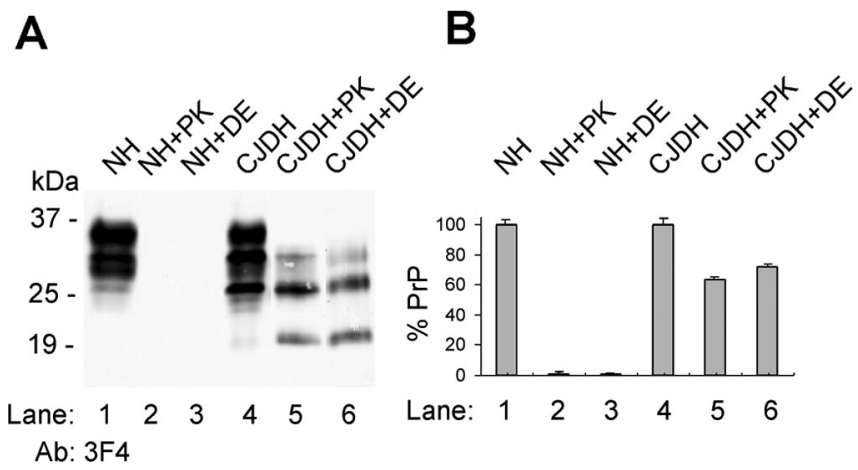

Figure 1. Human $\mathrm{SCDD}-\mathrm{PrP}^{\mathrm{Sc}}$ is partially proteolyzed by DEs. $A$, Immunoblotting of $\mathrm{NH}$ and CJDH with 3F4 shows the three glycoforms of PrP migrating at 35-37, 28-30, and 27 kDa (lanes 1, 4). Treatment of NH with PK or DE results in almost complete digestion of $\operatorname{PrP}^{C}($ lanes 2,3$)$, whereas similar treatment of $\mathrm{CJDH}$ results in $\mathrm{N}$-terminally truncated $\mathrm{PrP}^{\mathrm{Sc}}$ forms migrating at $19-30 \mathrm{kDa}$ (lanes 5, 6). B, Densitometric analysis indicates hydrolysis of $97-98 \%$ of PrP ${ }^{C}$ in $\mathrm{NH}$ by PK or DE, whereas PrP ${ }^{S C}$ in CJDH shows limited resistance to PK (68\%) and DE (75\%).

and pathogenic PK-resistant $\operatorname{PrP}^{\mathrm{Sc}}$ (Fig. $1 A$, lanes 5, 6). Although this outcome is expected after PK treatment of CJDH, the generation of similar glycoforms with DE is noteworthy, suggesting comparable cleavage of $\mathrm{PrP}^{\mathrm{Sc}}$ by the two procedures. Additional confirmation of DE-mediated cleavage of $\mathrm{PrP}^{\mathrm{Sc}}$ was obtained by reblotting $\mathrm{PK}$ - and DE-treated $\mathrm{CJDH}$ samples with antibodies specific to the $\mathrm{N}$ or $\mathrm{C}$ terminus of PrP. As expected, there was no immunoreaction with the N-terminal antibody $8 \mathrm{~B} 4$ and strong reactivity with C-terminal antibody $8 \mathrm{H} 4$ (data not shown). Evaluation of sCJD brain homogenate after treatment with individual DEs revealed that the cleavage of $\mathrm{PrP}^{\mathrm{Sc}}$ is mediated by pepsin at pH 2.0 (data not shown).

Quantitative estimation of the above results shows that 2 and $3 \%$ of $\operatorname{PrP}$ in $\mathrm{NH}$ samples and 68 and $75 \%$ of $\operatorname{PrP}$ in $\mathrm{CJDH}$ samples resist $\mathrm{PK}$ and $\mathrm{DE}$ treatment, respectively (Fig. $1 B$ ). Thus, by the time ingested $\mathrm{PrP}^{\mathrm{Sc}}$-contaminated meat reaches the intestine, almost all of $\mathrm{PrP}^{\mathrm{C}}$ is proteolyzed, and $\mathrm{PrP}^{\mathrm{Sc}}$ is converted to the protease-resistant C-terminal core of $27-30 \mathrm{kDa}$.

\section{DE-treated sCJD-PrP ${ }^{\mathrm{Sc}}$ is transported across Caco-2 epithelial cells}

The transport of $\mathrm{PrP}^{\mathrm{C}}$ and $\mathrm{PrP}^{\mathrm{Sc}}$ in $\mathrm{NH}$ and $\mathrm{CJDH}$ across intestinal epithelial cells was assessed in an in vitro model comprising Caco-2 cell monolayers with tight junctions (Pinto et al., 1983). For all experiments, Caco-2 monolayers exhibiting a TEER of $>400 \Omega / \mathrm{cm}^{2}$ and ${ }^{3} \mathrm{H}$-inulin transport from the AP chamber to the BL chamber of $<0.01 \% / \mathrm{cm}^{2} / \mathrm{min}$ were used. Transport of ${ }^{3} \mathrm{H}$-inulin was compared before and after each treatment to rule out any toxic effects of the homogenate or $\mathrm{PrP}^{\mathrm{Sc}}$ during the experiment. Each sample was tested in duplicate, and each experiment was repeated at least five times.

In a typical experiment, $20 \mu \mathrm{l}$ of $\mathrm{NH}$ or $\mathrm{CJDH}$ that had been mock treated, PK treated, DE treated, or DE treated and mixed with the PrP peptide 106-126 (10 $\mu \mathrm{M})$ was added to the AP chamber of Caco-2 monolayers in serum-free medium and incubated overnight at $37^{\circ} \mathrm{C}$. Subsequently, medium was collected from the AP and BL chambers, and methanol-precipitated proteins from the media and cell lysate samples were fractionated by SDS-PAGE, transblotted to a PVDF membrane, and probed with 3F4. In the NH sample, practically all of the added PrP is recovered from the AP medium, indicating negligible transport to the BL chamber (Fig. 2A, lanes 1-3). As expected, NH-PK and NH-DE samples show barely detectable PrP signal in the AP or 
A
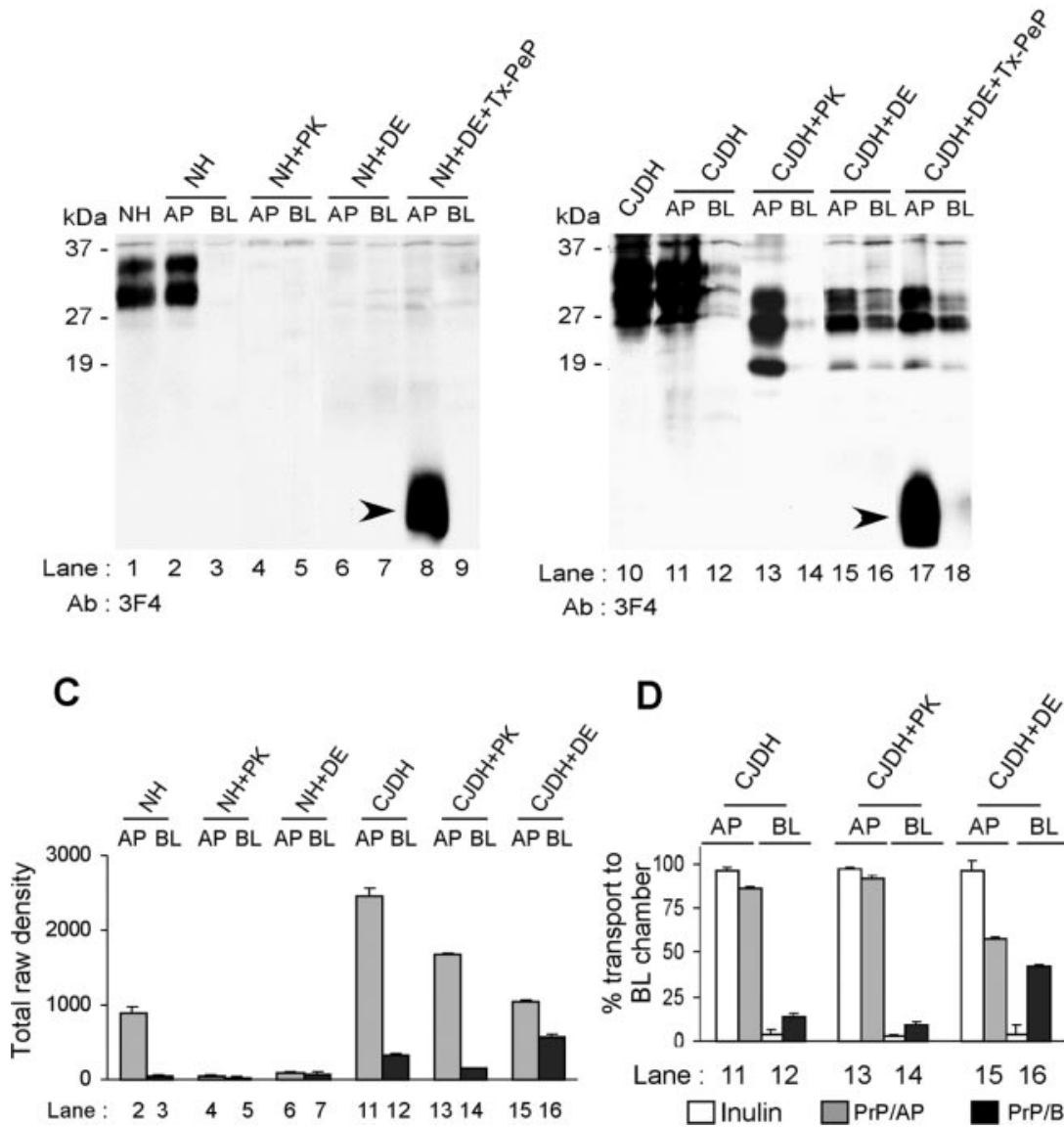

B

D

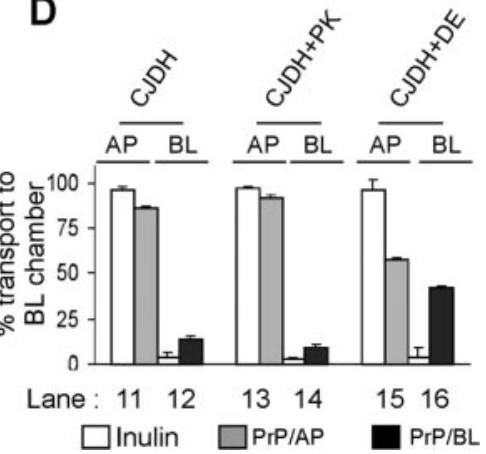

Figure 2. DE-treated SCJD-PrP ${ }^{S c}$ is transported across Caco-2 epithelial cells. An aliquot of mock-treated, PK-treated, or DE-treated NH or CJDH was added to the AP chamber of Caco-2 monolayers, and PrP transported to the BL chamber was estimated after an overnight incubation. $A$, Immunoblotting of proteins from the AP and BL media with $3 F 4$ shows no detectable PrP signal in the BL chamber of cells exposed to mock-treated (lanes 2, 3), PK-treated (lanes 4, 5), or DE-treated (lanes 6-9) NH. B, In contrast, a significant PrP signal is detected in the BL chamber of cells exposed to mock-treated (lanes 11, 12), PK-treated (lanes 13, 14), or DE-treated (lanes 15-18) CJDH. PrP peptide 106-126 (Tx-pep) is not transported to the BL chamber when mixed with either DE-treated NH ( $A$; lanes 8, 9, arrowhead) or DE-treated CDDH ( $B$; lanes 17, 18, arrowhead). Lanes 1 and 10 show PrP reactivity in the starting $\mathrm{NH}$ and $\mathrm{CJDH}$ samples, respectively. C, Measurement of total raw density of PrP signal indicates minimal transport of PrP from mock-treated NH. In PK-treated and DE-treated NH samples, as expected, minimal PrP signal is detected. In contrast, a prominent PrP signal is detected in the AP and BL chambers of monolayers exposed to similarly treated CDDH samples (lane numbers correspond to samples in $A$ and $B$ ). D, Quantitative estimation shows transport of $14,8.5$, and $42 \%$ of PrP from the AP chamber to the BL chamber from mock-treated, PK-treated, and DE-treated CJDH, respectively. Transport of ${ }^{3} \mathrm{H}$-inulin was $<0.01 \% / \mathrm{cm}^{2} / \mathrm{min}$ before and after the completion of each experiment. The error bar represents the mean $\pm S D$ of four experiments. $p<0.01$.

BL samples (Fig. 2A, lanes 4-7). However, PrP106-126 (toxic peptide) is easily detected in the AP medium of NH-DE plus toxic peptide sample, ruling out experimental error in the detection of any leftover PrP (Fig. $2 A$, lane 8, arrowhead). In contrast, PrP in $\mathrm{CJDH}$ and protease-resistant $\mathrm{PrP}^{\mathrm{Sc}}$ in $\mathrm{PK}$ - and DE-treated CJDH samples are transported to the BL chamber (Fig. 2B, lanes 1016). Surprisingly, $\mathrm{PrP}^{\mathrm{Sc}}$ in DE-treated $\mathrm{CJDH}$ is transported more efficiently than from the PK-treated sample (Fig. 2B, lanes 1318). The PrP106-126 peptide mixed with CJDH-DE is not transported, although a bold $\mathrm{PrP}^{\mathrm{Sc}}$ signal is detected in the $\mathrm{BL}$ chamber of CJDH-DE plus toxic peptide sample (Fig. 2 B, lanes 17, 18, arrowhead). No PrP signal was detected in any of the Caco-2 lysate samples (data not shown).

Quantification of the PrP signal in the AP and BL chambers of monolayers exposed to $\mathrm{NH}$ or $\mathrm{CJDH}$ and the percentage of transport of PrP in CJDH from the AP to the BL chamber are shown in
Figure 2, $C$ and $D$, respectively. In the mock-treated NH sample, almost all $\mathrm{PrP}$ is recovered from the AP chamber, with insignificant transport to the $\mathrm{BL}$ chamber (Fig. 2C, lanes 2, 3). In the PK- and DEtreated NH samples, as expected, barely any $\mathrm{PrP}$ is detected in the AP or BL chambers (Fig. 2C, lanes 4-7). In contrast, a significant proportion of $\mathrm{PrP}^{\mathrm{Sc}}$ from the $\mathrm{CJDH}$ samples is transported from the AP to the BL chambers (Fig. 2C, lanes 11-16), representing a transport of $14,8.5$, and $42 \%$ of $\mathrm{PrP}^{\mathrm{Sc}}$ from mock-treated, PKtreated, and DE-treated CJDH, respectively (Fig. 2D, lanes 11-16). The transport of ${ }^{3} \mathrm{H}$ inulin across the same monolayer is $<0.01 \% / \mathrm{cm}^{2} / \mathrm{min}$ in $1 \mathrm{hr}$ at $37^{\circ} \mathrm{C}$ (Fig. $2 \mathrm{D}$ ), confirming the integrity of tight junctions under these experimental conditions.

\section{Overexpression of $\operatorname{PrP}^{\mathrm{C}}$ does not alter the transport of sCJD-PrP ${ }^{\mathrm{Sc}}$ across Caco- 2 cells}

To evaluate whether the level of $\operatorname{PrP}^{C}$ expression on Caco-2 cells influences $\mathrm{PrP}^{\mathrm{Sc}}$ uptake or transport, Caco-2 cells were transfected with a plasmid encoding human $\operatorname{PrP}^{\mathrm{C}}$, and the percentage of increase in $\mathrm{PrP}^{\mathrm{C}}$ expression was estimated. Immunoblotting of cell lysates prepared from human neuroblastoma, nontransfected Caco-2, and $\mathrm{PrP}^{\mathrm{C}}$-transfected Caco-2 $\left(\mathrm{Caco}-2^{\mathrm{PrP}}\right.$ ) cells with $3 \mathrm{~F} 4$ shows a 2.5 -fold increase in $\operatorname{PrP}^{\mathrm{C}}$ expression by Caco- $2^{\mathrm{PrP}}$ cells compared with nontransfected Caco- 2 cells and 1.25 times that of M17 neuroblastoma cells (Fig. 3A, lanes 1-3, B).

The influence of increased $\operatorname{PrP}^{\mathrm{C}}$ expression on $\mathrm{PrP}^{\mathrm{Sc}}$ transport was estimated by isolating a crude fraction of $\mathrm{PrP}^{\mathrm{Sc}}$ from $\mathrm{PK}$-treated CJDH to avoid the influence of membrane in mediating $\operatorname{PrP}^{\mathrm{Sc}}$ transport (Baron and Caughey, 2003). Accordingly, $20 \mu \mathrm{l}$ of PK-treated CJDH was methanol precipitated, and the pellet was resuspended in PBS and added to the AP chamber of Caco-2 and Caco-2 ${ }^{\operatorname{PrP}}$ monolayers. After an overnight incubation, AP and BL media were analyzed by immunoblotting and densitometric analysis as above. No significant difference is observed in the amount of $\mathrm{PrP}^{\mathrm{Sc}}$ transported across Caco- $2{ }^{\operatorname{PrP}}$ compared with nontransfected Caco-2 cells (Fig. 3C, lanes $1-4, D$ ). These results were further confirmed by comparing the transport of $\mathrm{PrP}^{\mathrm{Sc}}$ across HT-29 cells, another human intestinal epithelial cell line that expresses twofold more $\mathrm{PrP}^{\mathrm{C}}$ than Caco-2. No significant difference was observed in the rate or quantity of $\mathrm{PrP}^{\mathrm{Sc}}$ transported across Caco- 2 and HT-29 cells (data not shown), suggesting that the host $\operatorname{PrP}^{\mathrm{C}}$ expression level does not influence the internalization of $\operatorname{PrP}^{\mathrm{Sc}}$ by epithelial cells.

\section{Protease-resistant human $\mathrm{SCJD}-\mathrm{PrP}^{\mathrm{Sc}}$ is associated with ferritin}

We next attempted to purify $\operatorname{PrP}^{\mathrm{Sc}}$ from sCJDH to determine the impact of other molecules or proteins on its transport across 
Caco-2 cells. Thus, sCJDH was subjected to $\mathrm{PK}$ treatment and repeated rounds of ultracentrifugation as described in Materials and Methods. The clarified supernatant from CJDH (S1), the supernatant and pellet fractions after the first round of ultracentrifugation ( $\mathrm{S} 2$ and $\mathrm{P} 2$, respectively), and four subsequent rounds of ultracentrifugation (S3-S6 and P3-P6) were precipitated with cold methanol, fractionated by SDS-PAGE, and transblotted. Probing with 3F4 reveals PK-resistant glycoforms of $\mathrm{PrP}^{\mathrm{Sc}}$ representing the $\mathrm{N}$-terminal truncated diglycosylated, monoglycosylated, and unglycosylated forms migrating at 29 and 30, 22-25, and $19 \mathrm{kDa}$, respectively, in the $\mathrm{S} 1$ fraction (Fig. $4 A$, lane 1). After the first round of ultracentrifugation, $\sim 40 \%$ of $\mathrm{PrP}^{\mathrm{Sc}}$ fractionates in the supernatant fraction (S2), and $\sim 60 \%$ is detected in the pellet (P2) (Fig. 4A, lanes 2, 3). In subsequent rounds, all of the $\mathrm{PrP}^{\mathrm{Sc}}$ is detected in the pellet fractions (P3-P6) (Fig. 4A, lanes $5,7,9,11)$.

To assess the purity of $\mathrm{PrP}^{\mathrm{Sc}}$ recovered in the P6 fraction, the sample was deglycosylated with PNGase-F, fractionated by SDS-PAGE, and visualized by silver staining. In the untreated sample, bands corresponding to the diglycosylated, monoglycosylated, and unglycosylated forms of $\mathrm{PrP}^{\mathrm{Sc}}$ are identified as in Figure $4 A$ (Fig. $4 B$, lane 1$)$. In addition, a prominent band migrating at $20 \mathrm{kDa}$ is seen (Fig. $4 B$, lane 1). After deglycosylation, $\operatorname{PrP}^{\mathrm{Sc}}$ glycoforms collapse to $19 \mathrm{kDa}$ (Fig. $4 B$, lane 2, arrowhead), whereas the $20 \mathrm{kDa}$ band remains unchanged (Fig. 4B, lane 2, arrow). The band marked with an asterisk represents the added PNGase (Fig. 4B, lane 2). Sequencing of the $20 \mathrm{kDa}$ band confirmed its identity as a mixture of heavy $(\mathrm{H})$ and light (L) chains of ferritin. Additional verification was obtained by reprobing the membrane in Figure $4 A$ with anti-ferritin antibody. Strong immunoreaction is detected with the $20 \mathrm{kDa}$ band, confirming its identity as ferritin (Fig. 4C, lanes 1-11). It is remarkable that ferritin resists $\mathrm{PK}$ treatment and persistently pellets with $\operatorname{PrP}^{\mathrm{Sc}}$.

The above results argue that either $\operatorname{PrP}^{\mathrm{Sc}}$ and ferritin happen to cosediment or the two proteins form a complex with each other, perhaps through ionic or hydrophobic interactions. To distinguish between these possibilities, the P6 pellet fraction was treated with $\mathrm{NaCl}$ varying in concentration from 0.1 to $1.0 \mathrm{M}$, and ferritin was eluted using DEAE-cellulose chromatography. Immunoblotting of the eluted fractions with 3F4 and antiferritin antibody shows complete elution of ferritin at $0.4 \mathrm{M} \mathrm{NaCl}$ (Fig. 4D, bottom, lanes 1-6). Almost all of the $\operatorname{PrP}^{\mathrm{Sc}}$ is retained in the column and is barely detected in the eluate (Fig. $4 D$, top, lanes 1-6).

Thus, $\mathrm{PrP}^{\mathrm{Sc}}$ and ferritin in the sCJD brain homogenate form a complex that is resistant to dissociation with low concentrations
B

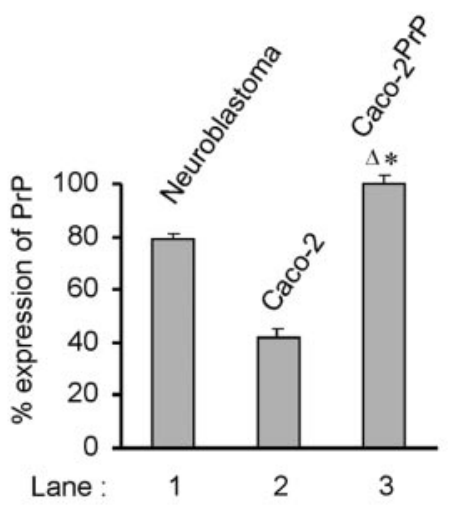

D

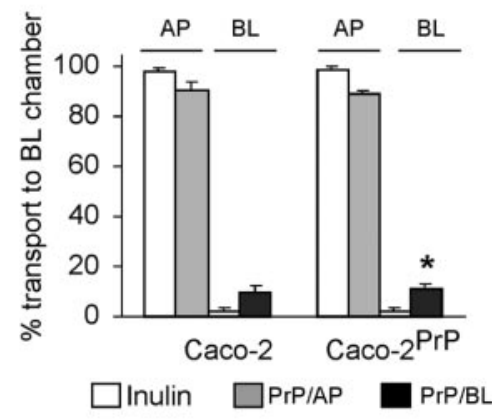

Figure 3. Overexpression of $\operatorname{PrP}^{\mathrm{C}}$ does not influence the transport of SCJD-PrP $\mathrm{Sc}^{\mathrm{C}}$ across Caco-2 monolayers. Lysates of M17 expression. A, Transfected Caco-2 ${ }^{\text {PrP }}$ expresses significantly more PrP compared with M17 and nontransfected Caco-2 cells (lane 3 vs lanes 1,2). B, Quantitative estimation shows 2.5 - and 1.5-fold PrP expression in Caco-2 ${ }^{\text {PrP }}$ cells compared with nontransfected PK-resistant PrP ${ }^{\mathrm{Sc}}$ across Caco-2 and Caco- ${ }^{\mathrm{PrP}}$ cell monolayers was measured as in Figure 2. There is no significant difference in 列 lanes 1, 2).D, Quantitative estimation shows transport of 10 and $11.2 \%$ of $\mathrm{PrP}^{\mathrm{SC}}$ to the BL chamber of Caco-2 and Caco-2 ${ }^{\mathrm{PrP}}$ cell monolayers, respectively. Each bar represents the mean \pm SD of three experiments. ${ }^{*} p<0.05$.

of salt. Whether this interaction occurs in the brain in vivo or after homogenization of brain tissue is unclear from our data.

Because it is unlikely that an aggregated and insoluble $\mathrm{PrP}^{\mathrm{Sc}}$ ferritin complex would be transported across the epithelial cell barrier, we focused our additional studies on the PK-resistant but detergent-soluble species of $\operatorname{PrP}^{\mathrm{Sc}}$ that is known to be infectious and can be immunoprecipitated with anti-PrP antibodies $8 \mathrm{H} 4$ and 6H4 (Safar et al., 1998; Paramithiotis et al., 2003; Pan et al., 2001). To determine whether protease-resistant, detergentsoluble $\mathrm{PrP}^{\mathrm{Sc}}$ is similarly associated with ferritin, mock-treated and DE-treated $\mathrm{NH}$ and $\mathrm{CJDH}$ were clarified by centrifugation at $3000 \times g$ and subjected to immunoprecipitation with either antiferritin or anti-PrP antibody $8 \mathrm{H} 4$. Immune complexes were collected with protein A beads and washed, and eluted proteins were analyzed by immunoblotting with 3F4 or anti-ferritin antibodies. In samples immunoprecipitated with anti-ferritin and probed with 3F4, minimal PrP signal is detected in $\mathrm{NH}$ and $\mathrm{NH}-\mathrm{DE}$ samples (Fig. 5A, lanes 1, 2). In contrast, surprisingly large 
B

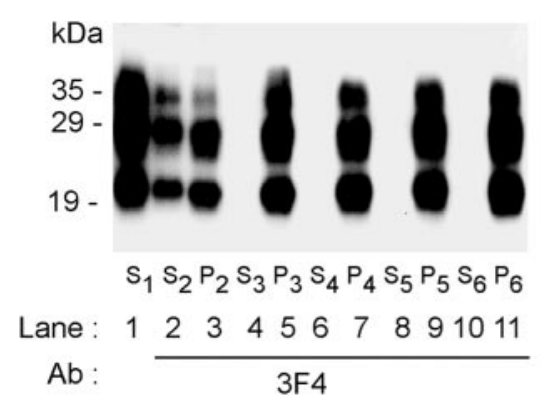

C

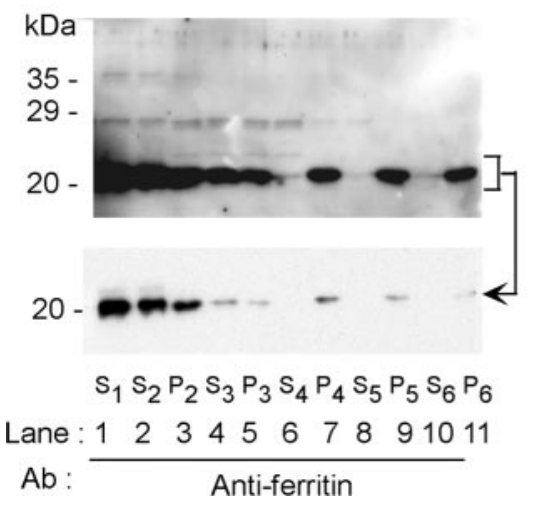

proteins from DE-treated $\mathrm{NH}$ and $\mathrm{CJDH}$ shows bands comigrating with ferritin at $20 \mathrm{kDa}$ and several unidentified proteins (Fig. 5A, lanes 11-14). No PrP was immunoprecipitated in the absence of primary antibody from either mock-treated or DEtreated $\mathrm{NH}$ or $\mathrm{CJDH}$, confirming that $\mathrm{PrP}^{\mathrm{Sc}}$ does not bind nonspecifically to protein A beads (Fig. 5B).

\section{sCJD-PrP ${ }^{\mathrm{Sc}}$ is cotransported with ferritin across Caco- 2 cells}

To determine whether $\mathrm{PrP}^{\mathrm{Sc}}$ is transported across Caco-2 cells in association with ferritin, $20 \mu \mathrm{l}$ of CJDH-DE in serumfree medium was added to the AP chamber of filter inserts containing Caco- 2 cell monolayers and incubated for $2 \mathrm{hr}$ at $37^{\circ} \mathrm{C}$. At the end of the incubation, monolayers were cut into two pieces: one half was immunostained for PrP and ferritin, and the other half was immunostained for the tight junction protein ZO-1. Transport of PrP and ferritin was checked by capturing horizontal confocal images at different depths as depicted in Figure $6 \mathrm{~A}$ and by taking vertical images.

Staining for PrP (green) and ferritin (red) at level I shows colocalization of PrP and ferritin (Fig. 6B, panels $1-3$, arrows) and limited reactivity for PrP alone (Fig. $6 B$, panels 1,3 , arrowheads). Similar images captured at level II (at the level of the filter pores) also show colocalization of PrP (green) and ferritin (red) (Fig. 6B, panels 4-6, arrows). Immunostaining for the tight junction protein ZO-1 (green) reveals intact tight junctions throughout the Caco-2 monolayer (Fig. 6B, panel 7). A vertical image through the same cells shows colocalization of $\operatorname{PrP}$ (green) and ferritin (red) at the AP and BL membranes (levels I and II) (Fig. 6B, panels 8-10). Transport of both $\mathrm{PrP}^{\mathrm{Sc}}$ and ferritin was significantly inhibited by incubation at $18^{\circ} \mathrm{C}$ and by pretreatment of the cells for 2

amounts of 3F4-immunoreactive $\operatorname{PrP}^{\mathrm{Sc}}$ from CJDH-DE and a small amount from $\mathrm{CJDH}$ sample coimmunoprecipitates with anti-ferritin (Fig. 5A, lanes 3, 4). Reprobing of the same membrane with anti-ferritin reveals the $\mathrm{H}$ and $\mathrm{L}$ chains of ferritin migrating at 21 and $20 \mathrm{kDa}$, respectively (Fig. 5A, lanes 5-8). In the CJDH-DE sample, additional slower migrating bands that react strongly with anti-ferritin antibody are detected (Fig. 5A, lane 8). Their identity is not clear at present. Immunoprecipitation of CJDH-DE with $8 \mathrm{H} 4$, followed by probing with 3F4 or anti-ferritin antibodies, shows similar association of $\operatorname{Pr} \mathrm{P}^{\mathrm{Sc}}$ with ferritin (Fig. 5A, lanes 9,10). The apparent difference in the amount of $\operatorname{PrP}^{\mathrm{Sc}}$ and ferritin that coimmunoprecipitate with anti-ferritin versus $8 \mathrm{H} 4$ is probably attributable to the nature of the specific antibodies (N. Morel et al., 2004). DE treatment partially hydrolyzes the $\mathrm{H}$ chain of ferritin, which comigrates with the $\mathrm{L}$ chain at $20 \mathrm{kDa}$ (Fig. 5A, lane 5 vs 6,7 vs 8 ).

Silver staining of anti-ferritin- and 8H4-immunoprecipitated hr with brefeldin-A $(3.5 \mu \mathrm{M})$ or nocodazole $(33 \mu \mathrm{M})$, implicating a transcytotic process (data not shown).

\section{sCJD-PrP ${ }^{\mathrm{Sc}}$ remains associated with ferritin after transcytosis}

To evaluate whether the $\mathrm{PrP}^{\mathrm{Sc}}$-ferritin complex remains intact after transcytosis across Caco-2 cells, filter inserts containing Caco-2 cell monolayers were placed in a 12-well dish containing M17 neuroblastoma cells cultured on glass coverslips in the BL chamber (Fig. 6A, diagram). Subsequently, $20 \mu \mathrm{l}$ of CJDH-DE or biotinylated CJDH-DE was added to the AP chamber. The biotinylated sample was used to distinguish added PrP and ferritin from endogenous proteins expressed by M17 cells. After an overnight incubation, transcytosed $\operatorname{PrP}^{\mathrm{Sc}}$ and ferritin that had been subsequently endocytosed by M17 cells in the BL chamber were detected by immunostaining (Fig. 7A). The presence of tight junctions in Caco-2 cell monolayers was confirmed by immuno- 
staining for ZO-1 and by checking the transport of ${ }^{3} \mathrm{H}$-inulin before and after incubation with CJDH-DE.

Immunostaining of Caco-2 monolayers for ZO-1 shows uniform staining, confirming the presence of tight junctions during the course of the experiment (Fig. $7 A$, panels 1,5$)$. Coimmunostaining of M17 cells for PrP (green) and ferritin (red) shows colocalization at several spots, indicating that some of the $\operatorname{PrP}^{\mathrm{Sc}}$-ferritin complexes remain intact even after transcytosis across Caco- 2 cells (Fig. 7A, panels 2-4). Coimmunostaining of M17 cells for $\operatorname{PrP}$ (green) and streptavidin (red) (Fig. 7A, panels 6-8) confirms that the PrP signal is derived from the transcytosed, biotinylated CJDH-DE added to the AP chamber.

Electron microscopic analysis of the $\mathrm{PrP}^{\mathrm{Sc}}$-ferritin complex immunoprecipitated with $8 \mathrm{H} 4$ (as in Fig. 5A, lanes 9, 13) shows fibrillar material decorated with ferritin aggregates (Fig. $7 B$, top inset, arrows). When added to a monolayer of Caco-2 cells, the $\mathrm{PrP}^{\mathrm{Sc}}$-ferritin complex is seen in small and large phagocytic vesicles enclosed by a single membrane with the fibrillar material intact within these vesicles (Fig. $7 B$, top). Groups of these vesicles are subsequently transported out from the BL membrane and are seen within the pore of the Transwell membrane (Fig. 7B, bottom).

Together, the above data demonstrate that the $\mathrm{PrP}^{\mathrm{Sc}}$-ferritin complex is endocytosed together by Caco- 2 cells and a significant proportion is transcytosed intact to the BL chamber, where it is endocytosed again by M17 cells.

\section{The binding of sCJD-PrP ${ }^{\mathrm{Sc}}$ to Caco-2 cells is partially inhibited by excess ferritin}

The persistent association of $\operatorname{PrP}^{\mathrm{Sc}}$ with ferritin before and after transcytosis led us to investigate whether ferritin acts as a facilitator or a mediator of $\mathrm{PrP}^{\mathrm{Sc}}$ transport across Caco-2 cells. Accordingly, an attempt was made to competitively inhibit the binding of $\mathrm{PrP}^{\mathrm{Sc}}$ by preincubating Caco-2 cells with increasing amounts of purified ferritin to saturate available ferritin-binding sites. Two different $\mathrm{PrP}^{\mathrm{Sc}}$ preparations were used for this purpose: (1) partially denatured biotin-tagged $\mathrm{PrP}^{\mathrm{Sc}}$ isolated from $\mathrm{CJDH}$ that copurifies with ferritin after ultracentrifugation; and (2) biotin-tagged $\mathrm{PrP}^{\mathrm{Sc}}$-ferritin in its native conformation in CJDH-DE. For competition, three different preparations were used: (1) pure human liver ferritin; (2) pure human spleen ferritin; and (3) brain ferritin purified from $\mathrm{NH}$ $\left(\mathrm{NH}^{\text {Pellet }}\right)$.

Biotin-tagged $\mathrm{PrP}^{\mathrm{Sc}}$ was purified by subjecting biotinylated $\mathrm{CJDH}$ to PK treatment and repeated rounds of ultracentrifugation, as in Figure 4. A sample from biotinylated $\mathrm{NH}$ was subjected
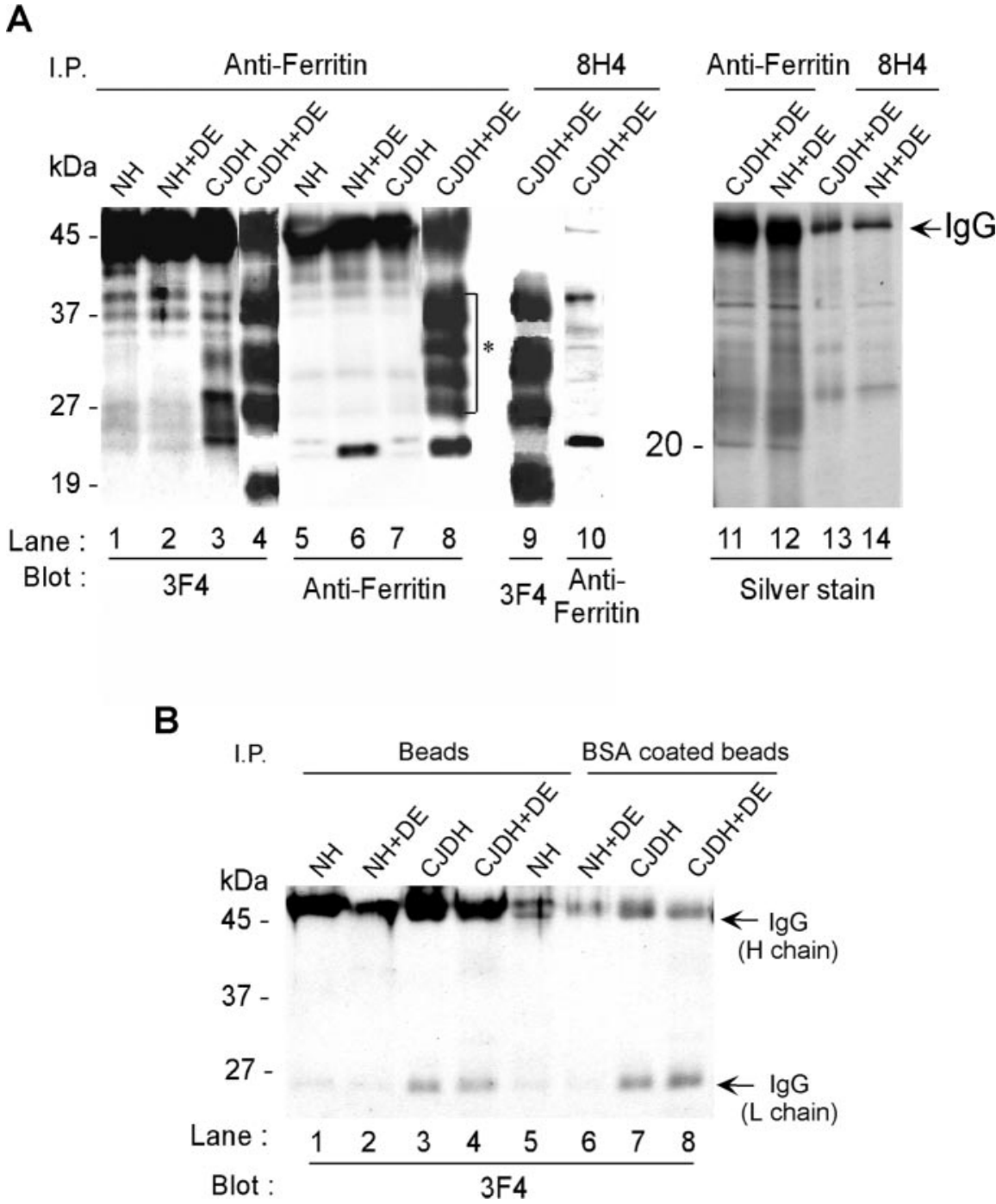

Figure 5. The PrP ${ }^{\mathrm{Sc}}$-ferritin complex coimmunoprecipitates with anti-ferritin and anti-PrP antibodies. Mock-treated or DEtreated NH and CJDH samples were immunoprecipitated (I.P.) with anti-ferritin or $8 \mathrm{H} 4$ antibodies, and coimmunoprecipitated proteins were detected by immunoblotting with specific antibodies. $A$, I.P. with anti-ferritin, followed by probing with $3 \mathrm{~F} 4$, shows no coimmunoprecipitation of $\mathrm{PrP}^{\mathrm{C}}$ from NH and NH-DE samples (lanes 1, 2). In contrast, full-length PrP ${ }^{\mathrm{Sc}}$ and a significantly greater amount of protease-resistant PrP ${ }^{\mathrm{Sc}}$ from CJDH and CDDH-DE immunoprecipitate with anti-ferritin (lanes 3, 4). Reprobing of the same membrane with anti-ferritin shows the $\mathrm{H}$ and $\mathrm{L}$ chains of ferritin migrating at 21 and $20 \mathrm{kDa}$ in both NH and CJDH samples (lanes 5, 7). The $\mathrm{H}$ chain comigrates with the $\mathrm{L}$ chain at $20 \mathrm{kDa}$ after DE treatment of NH and CJDH (lanes 6,8). The identity of additional ferritin-immunoreactive bands in the CJDH-DE sample is unclear (lane 8, * ). I.P. of CJDH-DE with 8H4, followed by probing with 3F4, shows PrP ${ }^{\mathrm{Sc}}$ bands similar to the ones detected with anti-ferritin I.P. (compare lanes 9, 4). Reprobing with anti-ferritin reveals the $20 \mathrm{kDa}$ ferritin band (lane 10). Silver staining of proteins immunoprecipitated with anti-ferritin or $8 \mathrm{H} 4$ shows bands comigrating with ferritin at $20 \mathrm{kDa}$ and several other minor species (lanes 11-14). Note that the lgG band in $8 \mathrm{H} 4$ immunoprecipitates is negligible because the antibody was conjugated to protein A beads. A similar conjugation of anti-ferritin reduced the amount of coimmunoprecipitated $\mathrm{PrP}{ }^{\mathrm{Sc}}$ significantly. $B$, No PrP bands are detected in the absence of primary antibody either with protein A beads or BSA-coated protein A beads (lanes 1-8).

to similar treatment, and the resulting pellet fractions from $\mathrm{NH}$ $\left(\mathrm{NH}^{\text {Pellet }}\right)$ and $\mathrm{CJDH}\left(\mathrm{CJDH}^{\text {Pellet }}\right)$ were evaluated by Western blotting and silver staining. As expected, immunoblotting with 3F4 shows no reactivity with the $\mathrm{NH}$ sample and strong reactivity with $\mathrm{N}$-terminally truncated $\mathrm{PK}$-resistant $\mathrm{PrP}^{\mathrm{Sc}}$ bands in the CJDH sample (Fig. 8A, lanes 1,2). Reprobing of the membrane with anti-ferritin antibody shows the presence of ferritin in both $\mathrm{NH}$ and CJDH samples (Fig. 8A, lanes 3, 4). Longer exposure shows the presence of $\mathrm{PrP}^{\mathrm{Sc}}$ and ferritin oligomers, despite treatment with DTT and boiling in SDS sample buffer (Fig. $8 \mathrm{~A}$, lanes $5-8$, arrows). Silver staining of an aliquot from each sample 
A

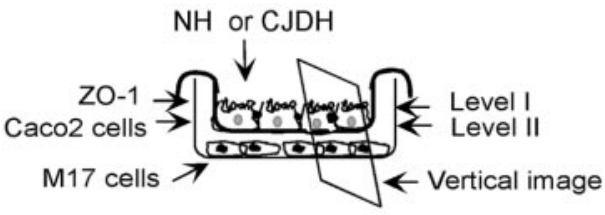

B
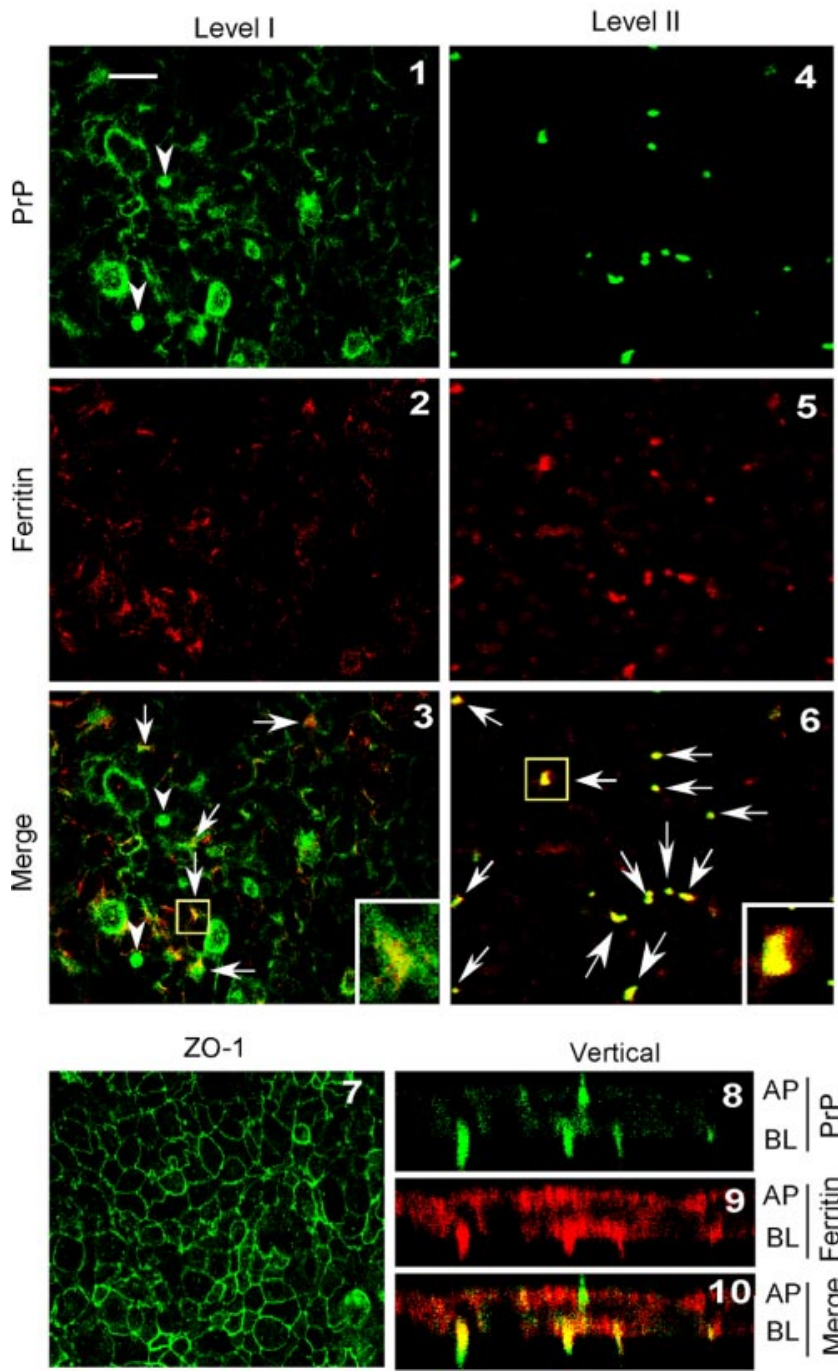

$8 \begin{aligned} & \mathrm{AP} \\ & \mathrm{BL}\end{aligned} \mid$

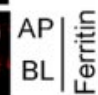
$10 \mathrm{AP}$ $\mathrm{BL} \mid \sum_{\Sigma}^{\infty}$

Figure 6. $s \mathrm{SJD}-\mathrm{PrP} \mathrm{Sc}^{\mathrm{s}}$ is cotransported with ferritin across Caco-2 cells. A, Diagrammatic representation of filter inserts with Caco-2 cell monolayers and the levels at which images were captured. M17 cells were cultured on glass coverslips in the BL chamber to capture transcytosed $\mathrm{PrP}^{\mathrm{Sc}}$-ferritin complexes (see Fig. 7A). B, Caco-2 cell monolayers were incubated with CJDH-DE in the AP chamber for $2 \mathrm{hr}$, and the filters were cut into two pieces. One was immunostained with 8H4 -anti-mouse FITC (green) and anti-ferritin-anti-rabbit RITC (red) (panels 1-6), and the other was immunostained with with anti-Z0-1-anti-rabbit FITC (green) (panel 7). A horizontal image at level I shows colocalization of PrP (green) and ferritin (red) on the AP surface of Caco-2 cells (panels 1-3, arrows). Some PrP immunoreaction without ferritin is also seen (green) (panels 1-3, arrowheads). A horizontal image captured at level II shows colocalization of PrP (green) and ferritin (red) at the filter pores (panels 4-6, arrows). Immunostaining for 20-1 shows the presence of tight junctions throughout the monolayer (panel 7). A vertical section through the Caco-2 monolayer shows similar colocalization of PrP (green) and ferritin (red) at the AP and BL membranes, as observed in the horizontal images (panels 8-10). Scale bar: $10 \mu \mathrm{m}$; inset, $2.5 \times$.

showed ferritin in the $\mathrm{NH}^{\text {Pellet }}$ and ferritin along with $\mathrm{PrP}^{\mathrm{Sc}}$ in the $\mathrm{CJDH}^{\text {Pellet }}$ samples, as in Figure 4 (data not shown).

To check whether the purified preparations bind to Caco-2 cells and whether this binding can be competitively inhibited by ferritin, $\mathrm{NH}^{\text {Pellet }}$ and $\mathrm{CJDH}^{\text {Pellet }}$ fractions were resuspended in purified human brain lipids lacking all proteins and sonicated to obtain a homogeneous mixture. Subsequently, polarized monolayers of Caco-2 cells were exposed to increasing amounts of $\mathrm{NH}^{\text {Pellet }}$ - and $\mathrm{CJDH}^{\text {Pellet }}$-brain lipid mixture diluted in PBS containing $1 \%$ BSA for $30 \mathrm{~min}$ on ice and processed for staining with Texas Red-streptavidin. Remarkably, cells exposed to both $\mathrm{NH}^{\text {Pellet }}$ and $\mathrm{CJDH}^{\text {Pellet }}$ show significant binding as determined by biotin-specific reactivity (Fig. $8 B$, panels $1,2,-$ Ferritin). Under the experimental conditions used, $16 \mu \mathrm{l}$ of $\mathrm{NH}^{\text {Pellet }}$ - and $\mathrm{CJDH}^{\text {Pellet}}$-brain lipid preparation gave a reproducible and specific signal of defined intensity and was used for competition experiments. Thus, cells were exposed to $0,0.5,1.0$, and $1.5 \mu \mathrm{g} / \mathrm{ml}$ human spleen ferritin resuspended in PBS containing 1\% BSA for $30 \mathrm{~min}$ on ice, washed, and reexposed to $16 \mu \mathrm{l}$ of $\mathrm{NH}^{\text {Pellet }}$ and $\mathrm{CJDH}^{\text {Pellet }}$ for an additional $30 \mathrm{~min}$ on ice. The amount of streptavidin-reactive material bound to Caco-2 cells was determined by staining with Texas Red-streptavidin. Under these experimental conditions, $1.5 \mu \mathrm{g} / \mathrm{ml}$ pure spleen ferritin inhibits the binding of $\mathrm{NH}^{\text {Pellet }}$ and $\mathrm{CJDH}^{\text {Pellet }}$ by $\sim 80 \%$, as determined by comparing the mean fluorescence intensity in 20 different fields (Fig. 8 B, panels $3,4,+$ Ferritin). Anti-ferritin- and PrP-specific antibodies were not used in this experimental setup because immunoreactivity is lost because of DTT treatment. The brain lipid used as vehicle did not show any reaction by itself (data not shown).

The binding of $\mathrm{NH}^{\text {Pellet }}$ that comprises only human brain ferritin and $\mathrm{CJDH}^{\text {Pellet }}$ that comprises partially denatured $\operatorname{PrP}^{\mathrm{Sc}}$ and ferritin and the inhibition of this binding by purified spleen ferritin suggest strongly that the binding of the $\operatorname{PrP}^{\mathrm{Sc}}$-ferritin complex to Caco-2 cells is mediated by ferritin, not by $\mathrm{PrP}^{\mathrm{Sc}}$.

Similar competition experiments were performed with biotin-tagged $\mathrm{PrP}^{\mathrm{Sc}}$ in CJDH-DE, a milieu in which it maintains reactivity to the anti-PrP antibody $8 \mathrm{H} 4$. The inhibition of $\operatorname{PrP}^{\mathrm{Sc}}$ binding in the presence of saturating amounts of ferritin was assessed by double staining with $8 \mathrm{H} 4$ and Texas Red-streptavidin. Although significant inhibition $(\sim 85 \%)$ of $\mathrm{PrP}^{\mathrm{Sc}}$ binding is observed in the presence of $1.5 \mu \mathrm{g} / \mathrm{ml}$ spleen ferritin, we did not observe a complete block (Fig. $8 C$, panels $1-6,-$ Ferritin and + Ferritin). Similar results were obtained when liver ferritin was used as a competitive inhibitor (data not shown).

Our inability to demonstrate $>80-85 \%$ inhibition of $\operatorname{PrP}^{\mathrm{Sc}}$ binding despite high concentrations of free ferritin as a competitor led us to conclude that liver and spleen ferritin may not be the optimal inhibitors. Because ferritin in $\mathrm{NH}^{\text {Pellet }}$ is similar to the ferritin in CJDH-DE in terms of the source and method of preparation, we used $\mathrm{NH}^{\text {Pellet }}$ to saturate available ferritin-binding sites on Caco- 2 cells before adding CJDH-DE. Thus, Caco-2 cells were exposed to $16 \mu \mathrm{l}$ of $\mathrm{NH}^{\text {Pellet }}$-brain lipid suspension for 30 min on ice, washed, and incubated for an additional $30 \mathrm{~min}$ on ice with $25 \mu$ l of CJDH-DE. The cells were then immunostained with $8 \mathrm{H} 4$ to detect bound $\mathrm{PrP}^{\mathrm{Sc}}$. Preincubation of the cells with $16 \mu \mathrm{l}$ of $\mathrm{NH}^{\text {Pellet }}$ inhibited the binding of $\mathrm{PrP}^{\mathrm{Sc}}$ by $\sim 90 \%$ (Fig. $8 D$, panels 1, 2, $-\mathrm{NH}^{\text {Pellet }}$ and $+\mathrm{NH}^{\text {Pellet }}$ ).

Together, the above results suggest strongly that ferritin plays a significant role in the binding and transport of the $\operatorname{PrP}^{\mathrm{Sc}}$-ferritin complex across Caco-2 cells.

\section{Discussion}

This report provides insight into the pathway of $\operatorname{PrP}^{S c}$ uptake and transport across intestinal epithelial cells. In particular, our data show that exposure of SCJD brain homogenate to DEs generates a C-terminal $\mathrm{PrP}^{\mathrm{Sc}}$ core of $27-30 \mathrm{kDa}$ that is transported across 
Caco-2 cells in vesicular structures and that this process is not influenced by the level of endogenous $\operatorname{PrP}^{\mathrm{C}}$ expression. Within these vesicles, $\operatorname{PrP}^{\mathrm{Sc}}$ is associated with ferritin, a major component of the $\mathrm{PrP}^{\mathrm{Sc}}$-protein complex, and remains associated with ferritin after transcytosis. Because ferritin is normally absorbed from food and is abundantly present in a typical meat dish, these findings have important implications for prion uptake from contaminated food.

Using the well tested in vitro model for evaluating intestinal uptake of selected food nutrients (Cereijido et al., 1978; Pinto et al., 1983; Glahn et al., 1998), we show the resilience of $\mathrm{PrP}^{\mathrm{Sc}}$ to DEs and the facilitative effect of such treatment on $\mathrm{PrP}^{\mathrm{Sc}}$ uptake by Caco- 2 cell monolayers. We noted that after treatment of CJDH with stomach pepsin, $\operatorname{PrP}^{\mathrm{Sc}}$ underwent limited proteolysis and comigrated with the C-terminal PK-resistant core of $\mathrm{PrP}^{\mathrm{Sc}}$. Under similar conditions, $\mathrm{PrP}^{\mathrm{C}}$ in the $\mathrm{NH}$ was completely hydrolyzed. Much to our surprise, DE-treated $\mathrm{PrP}^{\mathrm{Sc}}$ was transported across Caco-2 cells four times more efficiently than $\mathrm{PK}$-treated $\mathrm{PrP}^{\mathrm{Sc}}$. We believe that this effect is attributable to the chaotropic effect of bile salts that disperse $\mathrm{PrP}^{\mathrm{Sc}}$-containing membrane phospholipds into small micelles, preventing the aggregation of $\mathrm{PrP}^{\mathrm{Sc}}$ and facilitating its binding to epithelial cells. This observation has significant practical implications because there could be qualitative and/or quantitative differences in the digestive process between individuals and certainly between different species. Such differences, although subtle and apparently trivial, may influence host susceptibility to prion infection from contaminated food.

While purifying $\mathrm{PrP}^{\mathrm{Sc}}$ from $\mathrm{CJDH}$, we noted that the $\mathrm{H}$ and $\mathrm{L}$ chains of ferritin consistently cosediment with $\operatorname{PrP}^{\mathrm{Sc}}$. Resistance of the $\operatorname{PrP}^{\mathrm{Sc}}$ ferritin complex to elution with low concentrations of salt and coimmunoprecipitation with either anti-PrP or anti-ferritin antibodies suggested an association between the two proteins, rather than coincidental sedimentation. Remarkably, both the $\mathrm{H}$ and $\mathrm{L}$ chains of ferritin resisted $\mathrm{PK}$ and DE treatment and were associated with the protease-resistant core of $\mathrm{PrP}^{\mathrm{Sc}}$. Electron microscopic examination of the $8 \mathrm{H} 4$-immunoprecipitated material revealed fibrils decorated with ferritin aggregates. Although other proteins were detected by silver staining of $8 \mathrm{H} 4$ and anti-ferritin immunoprecipitates attesting to the remarkably sticky nature of $\mathrm{PrP}^{\mathrm{Sc}}$, we believe that the association of $\mathrm{PrP}^{\mathrm{Sc}}$ with ferritin is stronger and is more likely to be of biological significance. This notion is based on the fact that after repeated rounds of ultracentrifugation, only ferritin remained associated with $\mathrm{PrP}^{\mathrm{Sc}}$, and the complex could be dissociated only with $0.4 \mathrm{M} \mathrm{NaCl}$. None of the other proteins copurified with $\operatorname{PrP}^{\mathrm{Sc}}$, suggesting that their coimmunoprecipitation with $\mathrm{PrP}^{\mathrm{Sc}}$ is perhaps attributable to nonspecific interactions with the antibodies or with $\operatorname{PrP}^{\mathrm{Sc}}$ itself (N. Morel et al., 2004). Whether
B

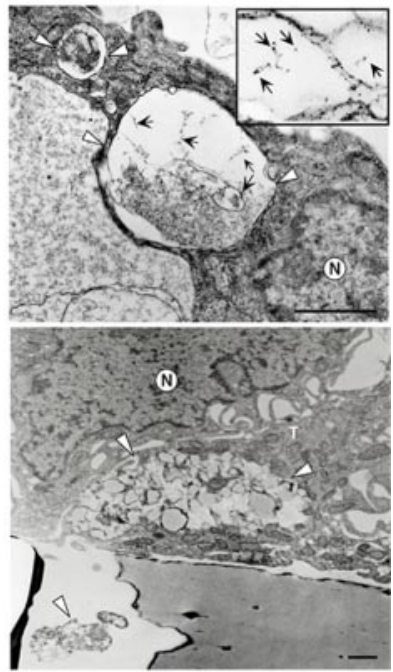

Figure 7. $\quad s C J D-P r P S c$ remains associated with ferritin after transcytosis. A, Caco-2 cell monolayers were placed in a 12-well to the AP chamber (see Fig. 6A). After an overnight incubation, Caco-2 cells on filters and M17 cells on coverslips were processed or immunostaining. Immunoreaction of filters with anti-Z0-1 shows the presence of tight junctions in all monolayers (green; proteins, indicating the presence of intact $\mathrm{PrP}^{\mathrm{Sc}}$-ferritin complexes after transcytosis (panels 2-4, arrows). Coimmunostaining of ( shows fibrillar structures and membranes decorated with ferritin aggregates (top inset; arrows). When added to (aco-2 cells, the cipitated material.) Scale bar: $0.25 \mu \mathrm{m}$; inset, $1.5 \times$. N, Nucleus; T, tight junction.

the association of $\mathrm{PrP}^{\mathrm{Sc}}$ and ferritin occurs in vivo or after homogenization of brain tissue is unclear from our data. Nevertheless, this complex is biologically significant because ingested $\mathrm{PrP}^{\mathrm{Sc}}$ in contaminated meat undergoes a process similar to homogenization and DE treatment in the GI tract and is likely presented to the intestinal epithelium in a complex with ferritin. Interestingly, the $\beta$-sheet-rich PrP peptide 106-126 mixed with normal or CJD homogenate was not transcytosed effectively, indicating that the main determinant of $\mathrm{PrP}^{\mathrm{Sc}}$ transport is not its $\beta$-sheet-rich secondary structure. Preincubation of PrP106-126, NH, or CJDH with exogenous purified ferritin did not facilitate the formation of coimmunoprecipitable PrPferritin complexes, indicating that the association of $\operatorname{PrP}^{\mathrm{Sc}}$ with ferritin is more complex than a mere hydrophobic interaction during the process of homogenization. Regardless of the nature and site of $\mathrm{PrP}^{\mathrm{Sc}}$-ferritin complex formation, this phenomenon is likely to influence the absorption of ingested $\mathrm{PrP}^{\mathrm{Sc}}$ significantly, especially because ferritin in ingested food is known to undergo active absorption by the human intestinal epithelium (Murray-Kolb et al., 2003; Theil, 2003). 
A
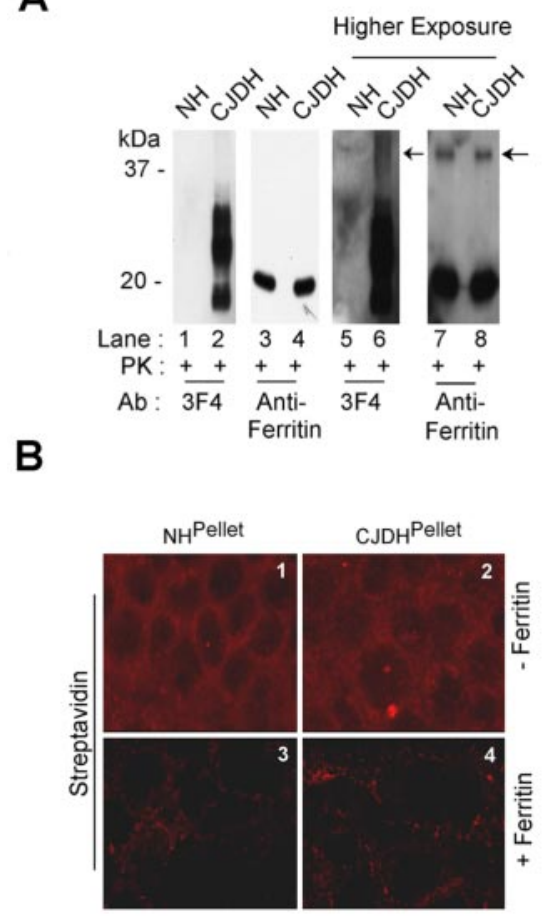

C

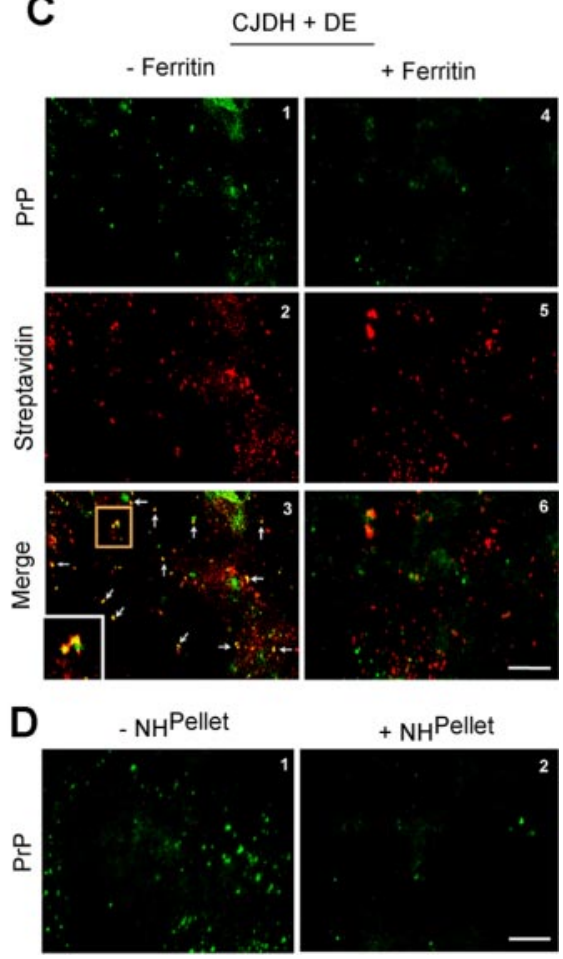

Our data show that $30-40 \%$ of ferritin from $\mathrm{NH}$ is consistently transcytosed across Caco-2 cells without degradation. In $\mathrm{CJDH}$, this amount varies with the size of $\mathrm{PrP}^{\mathrm{Sc}}$-ferritin aggregates. Small, detergent soluble complexes are transcytosed intact, whereas large, detergent insoluble aggregates remain on the monolayer in the AP chamber (R. S. Mishra and N. Singh, unpublished observations). These large aggregates may be internalized via M-cells, follicular dendritic cells, or bone marrowderived dendritic cells as reported previously (Heppner et al., 2001; Huang et al., 2002). It is conceivable that endocytosed ferritin is packaged in distinct vesicles that are either targeted to lysosomes or transcytosed to the $\mathrm{BL}$ surface. The associated $\mathrm{PrP}^{\mathrm{Sc}}$ in $\mathrm{CJDH}$ probably follows both routes, although the majority appears to be transcytosed because very little $\operatorname{PrP}^{\mathrm{Sc}}$ was detected in cell lysates (S. Basu and Singh, unpublished observations). This assumption is supported by the fact that a significant proportion of the $\operatorname{PrP}^{\mathrm{Sc}}-\mathrm{fer}$ ritin complex remains intact after transcytosis, as evidenced by coimmunostaining of endocytosed aggregates in M17 cells cultured in the $\mathrm{BL}$ chamber. $\operatorname{PrP}^{\mathrm{C}}$ from untreated $\mathrm{NH}$ did not show significant association with ferritin and was not transported to the BL chamber in several experiments. However, ferritin from untreated $\mathrm{NH}$ was detected consistently in the $\mathrm{BL}$ chamber (Basu and Singh, unpublished observations). Thus, either $\operatorname{PrP}^{\mathrm{C}}$ is not endocytosed at all or is degraded within Caco- 2 cells. A small amount of $\mathrm{PrP}^{\mathrm{Sc}}$ was detected occasionally independent of associated ferritin. It is unclear whether this fraction is associated with another protein, is transported independently, or results

Our results show that the $\operatorname{PrP}^{\mathrm{Sc}}$-ferritin complex is endocytosed by Caco- 2 cells in vesicular structures that fuse to form phagosomes within the cell. Some of these vesicles are transcytosed intact to the $\mathrm{BL}$ chamber, much like the reported release of $\mathrm{PrP}^{\mathrm{Sc}}$-containing exosomes into the extracellular environment by epithelial cells (Fevrier et al., 2004). Sensitivity of the $\mathrm{PrP}^{\mathrm{Sc}}$ ferritin transport to incubation at low temperature and treatment with brefeldin A and nocodazole suggest the involvement of an active transport process (Klausner et al., 1992). Although Caco-2 cells are known to endocytose ferritin, the mechanistic details of this process remain elusive (Murray-Kolb et al., 2003). Specific receptors for ferritin have been reported on liver cells, lymphocytes, erythroblasts, oligodendrocytes, and on various cell lines (Mack et al., 1983; Harrison and Arosio, 1996; Hulet et al., 2000). Our data demonstrating significant inhibition of $\operatorname{PrP}^{\mathrm{Sc}}$-ferritin uptake in the presence of excess ferritin derived from human liver, spleen, or brain suggests the presence of a ferritin-specific receptor or a transporter on Caco- 2 cells. The presence of such a receptor on epithelial cells and the close association of $\mathrm{PrP}^{\mathrm{Sc}}$ and ferritin in digested food incriminate ferritin as a possible transporter of $\mathrm{PrP}^{\mathrm{Sc}}$ across the intestinal epithelial cell barrier. from dissociation of the $\mathrm{PrP}^{\mathrm{Sc}}$-ferritin complex in an intracellular compartment.

The notion that $\operatorname{PrP}^{\mathrm{Sc}}$ is cotransported with ferritin ignores the key requirements of host susceptibility to prion infection, such as the level of $\mathrm{PrP}^{\mathrm{C}}$ expression and the extent of homology between host $\operatorname{PrP}^{\mathrm{C}}$ and incoming $\operatorname{PrP}^{\mathrm{Sc}}$ (Prusiner et al., 1990; Weissmann et al., 2002; Thackray et al., 2003). Although in apparent contradiction, our data suggest that the uptake of $\mathrm{PrP}^{\mathrm{Sc}}$ and its subsequent replication are distinct processes. The former is independent of host $\operatorname{PrP}^{C}$, whereas the latter requires $\operatorname{PrP}^{C}$ as substrate for additional replication. This hypothesis is supported by our data that show no influence of $\mathrm{PrP}^{\mathrm{C}}$ overexpression on $\mathrm{PrP}^{\mathrm{Sc}}$ transport across Caco-2 cells and by a recent report demonstrating $\operatorname{PrP}^{\mathrm{C}}$ expression below the tight junctions of polarized epithelial cells, making it physically impossible for incoming $\operatorname{PrP}^{\mathrm{Sc}}$ to come in contact with host $\operatorname{PrP}^{\mathrm{C}}$ (E. Morel et al., 2004).

The cotransport of $\mathrm{PrP}^{\mathrm{Sc}}$ with ferritin raises important questions regarding prion uptake from contaminated food. Although this report uses a homologous experimental setup, ferritin $\mathrm{H}$ and L chains are known to share significant homology across species (Harrison and Arosio, 1996) and may facilitate the transport of 
$\operatorname{PrP}^{\mathrm{Sc}}$ from distant species across the intestine. Because $\operatorname{PrP}^{\mathrm{Sc}}$ is notorious for its sticky nature, ferritin may be only one such carrier protein. The identification and functional role of other proteins associated with $\mathrm{DE}$-treated $\mathrm{PrP}^{\mathrm{Sc}}$ is important for fully understanding the mechanism of $\mathrm{PrP}^{\mathrm{Sc}}$ uptake from ingested food and preventing a carrier state across species. Heterologous $\mathrm{PrP}^{\mathrm{Sc}}$ in such carriers may be transported to sites where it may undergo conformational "adaptation" with time (Hill et al., 2000; Race et al., 2001), or in the case of livestock, lie dormant until ingested by a susceptible host. Such apparently "healthy" carriers would disseminate $\mathrm{PrP}^{\mathrm{Sc}}$ through a variety of means, posing a potential threat to the general population.

\section{References}

Aguzzi A, Polymenidou M (2004) Mammalian prion biology: one century of evolving concepts. Cell 116:313-327.

Baron GS, Caughey B (2003) Effect of glycosylphosphatidylinositol anchordependent and -independent prion protein association with model raft membranes on conversion to the protease-resistant isoform. J Biol Chem 278:14883-14892.

Beekes M, McBride PA (2000) Early accumulation of pathological PrP in the enteric nervous system and gut-associated lymphoid tissue of hamsters orally infected with scrapie. Neurosci Lett 278:181-184.

Bons N, Mestre-Frances N, Belli P, Cathala F, Gajdusek DC, Brown P (1999) Natural and experimental oral infection of nonhuman primates by bovine spongiform encephalopathy agents. Proc Natl Acad Sci USA 96:4046-4051.

Cereijido M, Robbins ES, Dolan WJ, Rotunno CA, Sabatini DD (1978) Polarized monolayers formed by epithelial cells on a permeable and translucent support. J Cell Biol 77:853-880.

Collinge J (1999) Variant Creutzfeldt-Jakob disease. Lancet 354:317-323.

Fevrier B, Vilette D, Archer F, Loew D, Faigle W, Vidal M, Laude H, Raposo G (2004) Cells release prions in association with exosomes. Proc Natl Acad Sci USA 101:9683-9688.

Foster JD, Parnham DW, Hunter N, Bruce M (2001) Distribution of the prion protein in sheep terminally affected with BSE following experimental oral transmission. J Gen Virol 82:2319-2326.

Glahn RP, Lee OA, Yeung A, Goldman MI, Miller DD (1998) Caco-2 cell ferritin formation predicts nonradiolabeled food iron availability in an in vitro digestion/Caco-2 cell culture model. J Nutr 128:1555-1561.

Gu Y, Verghese S, Mishra RS, Xu X, Shi Y, Singh N (2003a) Mutant prion protein-mediated aggregation of normal prion protein in the endoplasmic reticulum: implications for prion propagation and neurotoxicity. J Neurochem 84:10-22.

Gu Y, Hinnerwisch J, Fredricks R, Kalepu S, Mishra RS, Singh N (2003b) Identification of cryptic nuclear localization signals in the prion protein: implications for prion disease pathogenesis. Neurobiol Dis 12:133-149.

Haik S, Faucheux BA, Sazdovitch V, Privat N, Kemeny J-L, Perret-Liaudet A, Hauw J-J (2003) The sympathetic nervous system is involved in variant Creutzfeldt-Jakob disease. Nat Med 9:1121-1123.

Harrison PM, Arosio P (1996) The ferritins: molecular properties, iron storage function and cellular regulation. Biochim Biophys Acta 1275:161-203.

Heppner FL, Christ AD, Klein MA, Prinz M, Fried M, Kraehenbuhl J-P, Aguzzi A (2001) Transepithelial prion transport by M cells. Nat Med 7:976-977.

Hill AF, Sidle KC, Joiner S, Keyes P, Martin TC, Dawson M, Collinge J (1998) Molecular screening of sheep for bovine spongiform encephalopathy. Neurosci Lett 255:159-162.

Hill AF, Joiner S, Linehan J, Desbruslais M, Lantos PL, Collinge J (2000) Species-barrier-independent prion replication in apparently resistant species. Proc Natl Acad Sci USA 97:10248-10253.

Huang FP, Farquhar CF, Mabbott NA, Bruce ME, MacPherson GG (2002) Migrating intestinal dendritic cells transport $\operatorname{PrP}^{\mathrm{Sc}}$ from the gut. J Gen Virol 83:267-271.

Hulet SW, Heyliger SO, Powers S, Connor JR (2000) Oligodendrocyte progenitor cells internalize ferritin via clathrin-dependent receptor mediated endocytosis. J Neuron Res 61:52-60.

Klausner RD, Donaldson JG, Lippincott-Schwartz J (1992) Brefeldin A: in- sights into the control of membrane traffic and organelle structure. J Cell Biol 116:1071-1080.

Mack U, Powell LW, Halliday JW (1983) Detection and isolation of a hepatic membrane receptor for ferritin. J Biol Chem 258:4672-4675.

McBride PA, Schulz-Schaeffer WJ, Donaldson M, Bruce M, Diringer H, Kretzschmar HA, Beekes M (2001) Early spread of scrapie from the gastrointestinal tract to the central nervous system involves autonomic fibers of the splanchnic and vagus nerves. J Virol 75:9320-9327.

Miller MW, Williams ES (2003) Prion disease: horizontal transmission in mule deer. Nature 425:35.

Mishra RS, Gu Y, Bose S, Verghese S, Kalepu S, Singh N (2002) Cell surface accumulation of a truncated fragment of transmembrane prion protein in GSS P102L. J Biol Chem 277:24554-24561.

Morel E, Fouquet S, Chateau D, Yvernault L, Frobert Y, Pincon-Raymond M, Chambaz J, Pillot T, Rousset M (2004) The cellular prion protein $\operatorname{PrP}^{c}$ is expressed in human enterocytes in cell-cell junctional domains. J Biol Chem 279:1499-1505.

Morel N, Simon S, Frobert Y, Volland H, Mourton-Gilles C, Negro A, Sorgato MC, Creminon C, Grassi J (2004) Selective and efficient immunoprecipitation of the disease-associated form of the prion protein can be mediated by nonspecific interactions between monoclonal antibodies and scrapie-associated fibrils. J Biol Chem 279:30143-30149.

Murray-Kolb LE, Welch R, Theil EC, Beard JL (2003) Women with low iron stores absorb iron from soybeans. Am J Clin Nutr 77:180-184.

Nicotera P (2001) A route for prion neuroinvasion. Neuron 31:345-348.

Pan T, Colucci M, Wong BS, Li R, Liu T, Petersen RB, Chen S, Gambetti P, Sy MS (2001) Novel differences between two human prion strains revealed by two-dimensional gel electrophoresis. J Biol Chem 276:37284-37288.

Paramithiotis E, Pinard M, Lawton T, LaBoissiere S, Leathers VL, Zou W-Q, Estey LA, Lamontagne J, Lehto MT, Kondejewski L, Francoeur GP, Papadopoulos M, Haghighat A, Spatz SJ, Head M, Will R, Ironside J, O’Rourke K, Tonelli Q, Ledebur HC, et al. (2003) A prion protein epitope selective for the pathologically misfolded conformation. Nat Med 9:893-899.

Petersen RB, Parchi P, Richardson SL, Urig CB, Gambetti P (1996) Effect of the D178N mutation and codon 129 on the metabolism of the prion protein. J Biol Chem 271:12661-12668.

Peterson MD, Mooseker MS (1992) Characterization of the enterocyte-like brush border cytoskeleton of the $\mathrm{C} 2 \mathrm{BBe}$ clones of the human intestinal cell line, Caco-2. J Cell Sci 102:581-600.

Pinto M, Robine-Leon S, Appay M-D, Kedinger M, Triadou N, Haffen K, Fogh J, Zweibaum A (1983) Enterocyte-like differentiation and polarization of the human colon carcinoma cell line Caco- 2 in culture. Biol Cell 47:323-330.

Prinz M, Huber G, Macpherson AJS, Heppner FL, Glatzel M, Eugster H-P, Wagner N, Aguzzi A (2003) Oral prion infection requires normal numbers of Peyer's patches but not of enteric lymphocytes. Am J Pathol 162:1103-1111.

Prusiner SB (1998) Prions. Proc Natl Acad Sci USA 95:13363-13383.

Prusiner SB, Scott M, Foster D, Pan KM, Groth D, Mirenda C, Torchia M, Yang SL, Serban D, Carlson GA (1990) Transgenetic studies implicate interactions between homologous $\mathrm{PrP}$ isoforms in scrapie prion replication. Cell 63:673-686.

Race R, Raines A, Raymond GJ, Caughey B, Chesebro B (2001) Long-term subclinical carrier state precedes scrapie replication and adaptation in a resistant species: analogies to bovine spongiform encephalopathy and variant Creutzfeldt-Jakob disease in humans. J Virol 75:10106-10112.

Safar J, Wille H, Itri V, Groth D, Serban H, Torchia M, Cohen FE, Prusiner SB (1998) Eight prion strains have $\operatorname{PrP}^{\mathrm{Sc}}$ molecules with different conformations. Nat Med 4:1157-1165.

Taylor DM (2002) Current perspectives on bovine spongiform encephalopathy and variant Creutzfeldt-Jakob disease. Clin Microbiol Infect 8:332-339.

Thackray AM, Klein MA, Bujdoso R (2003) Subclinical prion disease induced by oral inoculation. J Virol 77:7991-7998.

Theil EC (2003) Ferritin at the crossroads of iron and oxygen metabolism. J Nutr 133:1549S-01553S.

Weissmann C, Enari M, Klöhn P-C, Rossi D, Flechsig E (2002) Transmission of prions. Proc Natl Acad Sci USA 99:16378-16383. 